\title{
Heritage and Knowledge. Apparatus, Logic and Strategies in the Formation of Heritage
}

\author{
Beatriz Santamarina \& Oriol Beltran
}

\begin{abstract}
Heritage as a category reflects diverse political positions. All heritagisation processes imply the creation of hierarchies, selection, ranking, and categorization of what is worthy or unworthy of being heritage, and all heritage creation involves certain disciplinary processes that confer legitimacy. As a modern invention, heritage was built on two closely-related cornerstones: the distinction between nature and culture and the difference between normalized knowledge and marginal knowledge. As a result, refining processes were applied which became strategies to legitimise political domination.

In this paper the constituent process of heritage creation and its links to normative knowledge are analysed, illustrating the various relationships between types of knowledge in the heritagisation process with the case of the Albufera Natural Park in Spain. A particular focus is placed on the processes that affect territories and natural resources, modifying the material conditions of the local population. Beyond giving rise to a mere acceptance of imposed expert knowledge, the analysed dynamics reveal the responsiveness of the local actors, as they make use of this knowledge in the context of a counter-hegemonic discourse.
\end{abstract}

Keywords: heritagisation processes; knowledge; legitimacy; production of truth; hegemonic policies

\section{Introduction}

The inhabitants of the small town of El Palmar, in the heart of the Albufera Natural Park in Valencia, Spain, make a certain linguistic distinction that is as interesting as it is telling. The staff of the park administration are all called by the same word by the locals: they are known as biólogos ("biologists"). Regardless of the job they do, or the administrative body they work for ${ }^{1}$, they are all referred to as biologists. This term entails a measure of irony, of criticism and of resistance. Irony, as the term is used as a kind of veiled insult owing to the type of field work they carry out in the area. Criticism, due to the perception of biologists as nerdish figures mesmerised by an encyclopaedic knowledge of their scientific discipline. And resistance, because the inhabitants of El

\footnotetext{
${ }^{1}$ The Servicio Devesa-Albufera del Ayuntamiento de Valencia and the Oficina Técnica de Gestión del Parque de Natural de la Albufera de la Generalitat Valenciana.
} 
Palmar are calling for legitimate recognition of the knowledge they have constructed over centuries in the day-to-day management of the Albufera lake. In this manner, they are standing up for tradition, seen as the essence of local wisdom - as a kind of powerful shield against authoritarian erudition.

Why do the inhabitants of El Palmar discredit the park experts with such a specific reference to a scientific discipline? Why do they refer to this particular discipline in such explicit terms? This symbolic battle, with important practical consequences, is difficult to explain in few words. We will return to this point below, but first these questions need to be framed within the context of our understanding of heritagebuilding policies. By using a term associated with university education, the locals are demonstrating their opposition to the expropriation they have suffered as a result of their land being designated as heritage, a process which is justified largely with scientific arguments. The endorsement of 'experts' is in fact a common procedure in natural, cultural and intangible heritagisation processes (following the categorisation established by UNESCO and adopted by most countries), promoted by politicians and bureaucrats, and as a result of which the people affected see the places they live in being taken away from them. Scientists (from scientia, knowledge in Latin) have the authority to grant a stamp of approval (of 'authentic' heritage), as they are the sources of knowledge and social recognition, and therefore those who define and shape reality. Thus, scientific knowledge, held as sacred in our modern culture, is used as a convenient tool to argue in favour of heritage-building policies.

In our view, heritage as a category reflects diverse political positions (Bendix 2009; Bendix, Eggert and Peselmann 2012; Smith 2006). Heritage is not an inherent reality, but a political construct characterised by reinvention, by the past and by identity. It is a reified metacultural artifact (Kirshenblatt-Gimblett 2004), producing asymmetries and inequalities, whilst generating a global and institutionalised system of, supposedly, unquestioned values (Herzfeld 2004; Palumbo 2010). In this process, hegemonic distinctions become authorised heritage discourses (Smith 2006), as well as prescriptive and performative meanings. This is represented in fields where different strategies and agents, as well as their structural asymmetric distribution of capital, come into play (Bourdieu 1980, 1994). It is important to remember that no elements or aspects exist which are intrinsically heritage (heritage 'things') (Harvey 2001; Kirshenblatt-Gimblett 
1998; Smith 2004, 2006); there are only heritagising agents (Montenegro 2010). If all heritagisation processes imply the creation of hierarchies, selection, ranking, and categorisation of what is worthy or unworthy of being heritage, and if in all heritage creation there are processes which involve certain disciplinary procedures which confer legitimacy, then how are these heritage distinctions made and which criteria are used? What procedures give the stamp of approval to heritage? Returning to our example: why do the inhabitants of El Palmar provide the term biologist with the above-mentioned meanings? Why do they use the designation with scorn?

We shall try to respond to the last two questions in this paper. Following this brief introduction we will describe the perspective from which we analyse the constituent process of heritage creation and its links to normative knowledge. We will look at the way in which heritage has been established, as well as its associated disciplines, after which we will return to the initial ethnographic context in the light of the ideas raised. Lastly, we will close with a reflection on the different roles that scientific knowledge can play, both in the creation of different types of heritage and in the use given to them by different social agents. To this end, we will use an ethnographic case that illustrates the various relationships between types of knowledge and how normalised knowledge can come to be used counter-hegemonically. This small sample will show us the potential of prescriptive knowledge and the close relationship between the heritage construct and the apparatus of science.

First, however, our understanding of scientific or expert knowledge, marginal or local knowledge, and heritage authenticity should be outlined. In the present paper, the concept of scientific or expert knowledge will be used to refer to knowledge which stems from the academic disciplines, which is endorsed by scientific methods, and which is turned into standardised knowledge capable of generating truth. In opposition, the notion of marginal / local knowledge will be used to refer to that which is based on the emplaced experience in a territory and which is constituted by a social corpus transmitted from generation to generation. The relations between these types of knowledge are as complex as they are hierarchical, and respond, as we shall see, to the practical modern distinction between knowledge and common sense. Some authors have differentiated between scientific and expert knowledge, on the one hand, and subjugated knowledge on the other, noting that both must be interpreted simultaneously as 
otherwise they are rendered meaningless. For Foucault (1980), subjugated knowledge is characterised by its discontinuity, disqualification and illegitimacy when facing the demands of a unified theoretical body capable of generating "true" knowledge based on its ability to create hierarchy and order.

In the case of the Albufera Natural Park, the local population's interpretation of the administration officers as biologists must be analysed within a context of unequal relations, and the demands of the local population should also be interpreted as the demands of producers of legitimate knowledge. This distinction between different types of knowledge is a tool for providing heritage processes with authenticity, through expert knowledge. Heritage authenticity, meanwhile, refers to the origin (Heinich 2009) or to the original (Boltanski and Chiapello 2002) and in epistemic terms, to the true (as opposed to the false, the artificial or the standardised). Despite the multiple meanings of the term, authenticity as an operational category refers to the authentication necessary for its implementation. The authorisation or legalisation of its attributes would be the responsibility of experts, in view of their expert knowledge (Davallon 2010; Frigolé 2014; Santamarina and Moncusí 2015). This shall be further explored below.

Last but not least, this work developed within a wider research on the socioeconomic transformations in the Albufera lake, and its relation with tertiarisation and patrimonialization processes.

Our study focuses on the Albufera territory and particularly on the population of El Palmar. The Albufera ecosystem consists of three different areas: the lake, the marshland and the meadow. Whilst each area could be defined by the use of its resources, fishing and rice cultivation have historically been the most prominent activities (Sanmartín 1979), and the lake has mainly been characterised by its use for fishing. From the late eighteenth century, this activity has been organised through fishing communities of the Silla, Catarroja and El Palmar villages. Since the Middle Ages, however, the community of El Palmar has been the only one with the privilege of redoli: the right to permanent fishing in the lake. Once the local resource par excellence, fishing is now clearly in decline. In the last century it was hampered first by silting (by which the agricultural area was increased at the expense of the lake) and by elver fishing in the Golas (exits to the sea) and later on also by water pollution. The marshland, on the other hand, was exploited mainly for rice cultivation (Soria and 
Vicente 2002). Finally, hunting has been an important activity in the Albufera territory, due to its historic, economic and symbolic value, providing fundamental income for the local population.

From an administrative point of view, El Palmar is a Valencian hamlet nestled in the Albufera. The population of this town grew at the expense of the island of the same name in the southeast of the lake. The appellation, 'El Palmar', refers not only to the town but also the Albufera lake itself. The hamlet is the Albufera fishing village par excellence; it is closely identified with the lake because its population is the only Valencian village that has traditionally enjoyed the privileges of permanent fishing.. During the last centuries, fishing has been the central activity of this town, supplemented, since the late nineteenth century, with rice cultivation. The fishermen of El Palmar in fact resisted the silting, criticising their neighbours for hampering fishing, until they eventually joined them (Sanmartin 1982; Santamarina and Vizcaino 2011). Historically the Community of Fishermen of El Palmar has regulated permanent and mobile fishing in the lake, organising the fishermen and representing their interests before the authorities and in conflicts with the rice cultivators. It was also responsible for the sale and distribution of fish and, as a cooperative, promoted the construction of housing and the distribution of farmland among its members. From its institutionalisation in the eighteenth century, it has been progressively consolidated, taking on functions not related to fishing, such as the implementation of the village school or the doctor's office. In this way, until a few decades ago, the Community of Fishermen was the social and economic backbone of El Palmar (Caruana 1954; Sanmartin 1982).

Starting in the 1960s and 1970s, the lake underwent a real transformation, experiencing an intense deterioration as a result of the rapid and disorderly industrialisation of the city of Valencia (Rosselló 1995). A large part of its landscape was profoundly altered, and the local population was forced to adapt their practices to new market demands. The intensification of this process during the following decades gave rise to a deep ecological crisis in the Albufera territory. The declaration of the area as Natural Park by the regional administration in 1986 was in recognition of both the exceptional nature of its ecosystem ("it is one of the most important natural areas in the Region of Valencia") and the serious situation it was facing ("the intense environmental degradation of the 
area"). Indeed, it was the first protected area of the Region of Valencia. The momentum of the heritagisation of nature as well as the new environmental conditions and markets pushed fishing into the background. The Albufera has turned into a major tourist attraction, leading to significant changes in the social and organizational structure of El Palmar, with fishing being displaced by tertiary activities. Yet the community still defines itself by its fishing character, claiming their rights over the lake and brandishing the Community of Fishermen as a legitimate institution of representation.

The ethnographic work was carried out between 2009 and 2012. It consisted mainly of conversations with key local people and outsiders working in the locality, as well as in collecting historic documentation, especially from the El Palmar Community of Fishermen Archive. This information was supplemented with observations in key sites and an analysis of secondary sources (official statistics from the local Council of Valencia and the Technical Service in the Albufera). The majority of the 32 interviews carried out (recorded digitally and then transcribed) were of biographical nature. Even though the interview sample considered representation in terms of gender, age and occupation, the present paper focuses mainly on the discourses of local fishermen, as those considering themselves the true custodians of the lake knowledge. They were the only people allowed to practice fishing in the past ${ }^{2}$ and they demand that they should be considered interlocutors for the Administration. The central role of the Community of Fishermen, backed by the local population and formed exclusively by local men, made us choose, for this particular paper, a specific profile of informants: older men who have practiced fishing since their youth and who have made of this activity their main livelihood until the fishing crises. In this text, we include some quotations from interviews with these men.

\section{Hegemonic Policies of Heritage Knowledge}

Rather than delving into the reifying, reductionist and exclusive character of heritage, which has already been a frequent subject of scholarly debate, we are interested in the principles that influence heritage creation and underpin its discourses and practical

\footnotetext{
${ }^{2}$ Further on we will delve into de transformations of the area, which will help us understand why after the 1960s and 1970s the younger people did not continue with the fishing activities which had been so common until then.
} 
application. This requires attention to the emergence and gradual growth of collective heritage, which started in the $19^{\text {th }}$ century and was consolidated throughout the $20^{\text {th }}$ century. The birth of the heritage construct, of the idea of heritage as social inheritance, is inseparable from the development of liberalism, capitalism and the nation state (Choay 1996; González-Varas 2003; Hernández et al. 2005; Poulot 2006). In fact, cultural, natural and intangible heritagisation processes ran parallel in time and endowed new political movements with patriotic topographies and a kind of historical continuity.

As a modern invention, heritage was built on two closely-related cornerstones: a distinction between nature and culture on the one hand, and the differentiation of normalised knowledge and marginal knowledge on the other. As a result, processes of refinement were applied and then turned into strategies to legitimise political domination. By creating independent domains, so-called cultural heritage was limited to the production of high culture, intangible heritage to popular knowledge, and natural heritage to scenic treasures (Bortolotto 2011; Hafstein 2011). Despite being organised as discrete realities, the types of logic used in implementing each kind of heritage (such as the allocation of a stamp of authenticity originating in a reinvented or mythic past) or in the institutions created to manage them (consider the musealisation of the different domains) were very similar. There were, however, two profound consequences to situating culture and nature as two independent domains. On the one hand, the commodification and objectification of realities destined to be subject to valuation and/or confiscation. On the other hand, a legitimisation that enabled paternalistic intervention in the naturalised domains (natural and intangible heritage) on the basis of cultural superiority, represented by creative genius (cultural heritage). This distinction made it easy to justify the subordinate and asymmetric position of nature and 'popular' culture in relation to Culture written in the singular and with a capital letter (Santamarina 2013). The distinction between normalised knowledge and marginal knowledge (which creates a dividing line between analytic and synthetic processes) worked in this direction and became a strategic distinction in allocating legitimacy within the context of the new political and economic regime. This distinction exists both within and outside our cultural practice. For some authors (such as Lander 2000, Escobar and Restrepo 2010, Ribeiro and Escobar 2008, among others) the coloniality of knowledge and the modern/colonial system-world were based on the creation of subaltern knowledge. Mignolo (2012) points out that universal knowledge was 
established thanks to a historical subject contextualised in various cultural centres. The classification of different modes of knowledge as different ways of accessing the 'truth' (the production of truth) was a central instrument of power (Foucault 1991; Haraway 1991; Maffesoli 1993, 1997; Mignolo 2012). Rational knowledge in the shape of 'technical' knowledge became an intrinsic attribute of power. As Foucault (1977, 27) noted, "there is no power relation without the correlative constitution of a field of knowledge, nor any knowledge that does not presuppose and constitute at the same time, power relations".

It is not insignificant that cultural, natural and intangible heritagisation appeared throughout the $19^{\text {th }}$ century alongside the development of corresponding scientific disciplines (Smith 2004). In our view, heritage construction as a political project is conceived as a programme subject to rational and scientific, (i.e., disciplinary) knowledge. This scientific-expert knowledge, as a creator of the evident or as a producer of reality effects (Comaroff and Comaroff 1991; Foucault 1970, 1991), has become a tool for legitimising heritage construction, sidelining other possible forms of recognition and knowledge. All this is presented as an exercise of distinction (Bourdieu 1984; García Canclini 1993), which guarantees a sweetened form of domination.

In addition, this strategy confers unquestionable advantages on political practice in at least two ways. Firstly, it gives legitimacy, not only to carry out its programme, but also by making it a paternalistic guardian over objects/subjects that have become heritagised and, therefore, subject to being watched over in the name of the imagined, experienced and constructed community (Heinich 2009). ${ }^{3}$ If there are elements of the past that must be conserved for the future, owing to their ennobled character and their capacity to articulate identity (Harvey 2008), they require vigilance. Vigilance, in turn, requires control and an apparatus to stand guard over them (Smith 2004). Secondly, the strategy makes it possible to divert attention away from the politico-economic field and to the scientific field, that is to say, to change the political arena in order to soften and divert any possible conflict. In other words, if heritage processes remain in the hands of experts and scientific activity is put forward as apolitical, given its supposed neutral

\footnotetext{
${ }^{3}$ Identity, as an open process, is neither solid nor permanent (Bauman 2004; Hall 2003). In this paper will not discuss the controversial and idealized term community (Bauman 2001)
} 
character, any problems derived from heritage construction (such as real and symbolic expropriation of a territory) will be masked. The burden no longer falls on political discourse, but rather on the experts: they are the agents responsible for dictating the appropriate measures for conserving, restoring or safeguarding heritage. The hegemonic dimension of heritage and the power condensed in the scientific discourses applied to heritage domains has been explored by several scholars (Briggs 1993, 1996; Smith 2004, 2006; Goldman 2001; Herzfeld 2006, 2010; among others). Broadly discussed in Anglo-American literature, this topic has also been explored in different Spanish scenarios (Del Mármol 2012; Del Mármol, Frigolé and Narotzky 2010; Franquesa 2013; Roigé and Frigolé 2010; Sánchez-Carretero 2012; Santamarina 2012; among others) as well as in Latino America (see, for example, Chaves, Montenegro and Zambrano 2014).

In this regard it is important to stress that we have witnessed significant changes in the notion of heritage patrimony from the nineteenth century to the twentieth, not only in relation to activations and agents (Ariño 2002) but also in terms of its conception (Heinich 2009). As for the latter, it is evident that the emphasis has changed in the institutionalized heritage discourse, as is clearly demonstrated in UNESCO's Convention for the Safeguarding of the Intangible Cultural Heritage of 2003. In brief, the discussion has moved from distinction to difference, from object to process, from technical confinement to community participation and from Eurocentrism to globocentrism. As some authors have argued, however, the new narrative framework is more rhetorical than real and the implemented heritage policies follow the same logic as before (Maguet 2011; Noyes, 2011; Santamarina 2013).

Scientific arguments are used to promote hegemonic conceptions which create expectations and enable exclusive topographies. We would like to highlight that these processes of dispute are diverted towards places where inequalities in the distribution of knowledge/power and in the arrangement of capital make it almost impossible to create a dialogue. For this reason, the local residents of El Palmar put all their frustration into their disparaging use of the word biologist for all managers. Biologists' knowledge, that specialist knowledge of nature, has become the only language heard by those implementing conservationist policies. While the use of the term biologist is a challenge to the construction of knowledge, an important clarification should be made: the use of scientific and technical knowledge as a legitimising tool is not only employed by 
heritage practitioners wielding authorised discourse (Smith 2006), but is also appropriated by marginal actors such as El Palmar locals themselves, who seek to equip themselves with orthodox arguments to achieve outcomes that diverge from those of park officials. The strategy of the practice of power is in a way appropriated by the resistance as a form of struggle. In this sense, the new heritage movements play by the same rules as the institutionalized political practice in order to counteract it.

\section{Ethnographic case: brief contextualization}

With this perspective in mind, let us return to our original ethnographic case. The Albufera Natural Park (21,120 hectares) was created in 1986 by the Valencian regional government in order to protect one of the most important wetlands in the territory. The legal status as Natural Park in the Spanish conservation legislation corresponds to category $\mathrm{V}$ of protected areas management categories established by UICN (protected landscape).

Albufera, situated some $12 \mathrm{~km}$ south of Valencia, is a coastal ecosystem with abundant natural resources in its lake, marshland and meadows. In 1990 it was included in the list of Wetlands of International Importance (Ramsar Convention) and it is protected under European agreements such as the SCI (Sites of Community Interest) and SPA (Special Protection Area) for birds. Following the creation of the park, new uses of the area were introduced and a symbolic, economic and legal reorganisation of the territory was begun which, years later, finally led to the approval of the Natural Resources Plan (PORN, in 1995) and the Master Plan for Uses and Management (PRUG, in 2004). These are planning and management instruments of the Spanish conservation legislation.

PORN is the planning tool for the management of natural resources and protection of species, and it establishes guidelines for PRUG as its provisions are binding. The former is compulsory and executive in all matters related to the conservation and protection of flora, fauna, ecosystems, landscape and natural resources, and prevails over any other planning document. In the case of the Albufera Natural Park this instrument establishes two priority areas for conservation: one with a higher level of protection and another with a lower level, which comprises, among other areas, vegetable and citrus crops and 
urban areas. ${ }^{4}$. Depending on the degree of protection, concrete conservation measures have been established for the conservation: of groundwater, riverbeds and riverbanks, of the soil and vegetation cover, of fauna and flora, of the coastline and the cattle trails, and for water use and management. Agricultural, livestock and forestry activities are also regulated, as well as industrial and extractive activities, as well as waste and infrastructure. Guidelines are defined for all activities, however, for activities related to the conservation of fauna and flora, the Natural Park can prohibit or authorise certain practices such as hunting or fishing.

PURG, on the other hand, is a more detailed document, which more clearly collects the various prohibitions. Regarding commercial fishing, it states that "traditional uses [...] are protected in the whole area of the park because of their social, economic and cultural interest", pointing out that the capture of all protected species of the aquatic fauna is prohibited. Elver fishing ${ }^{5}$ is also regulated, with the park's management bodies responsible for its seasonality, limitation or prohibition. With regard to hunting, several Game Reserve areas have been created, within which such activity is permanently prohibited.

Since the creation of the park, the inhabitants of El Palmar have had an ambiguous relationship with the political and administrative regime set up in the territory. As discussed, this town is defined primarily by its close links with the Albufera lake. El Palmar is right in the centre of the protected area. Although historically it was situated on one of the islands in the lake, in the 1930s it lost its island character when the first bridges were built (Rosselló 1995; Sanmartín 1982). The lake is such a fundamental aspect of identity for the locals that they call themselves 'albuferenses' (and not 'palmaristas', which would follow the name of the town). Fishing has been one of the main economic activities in El Palmar since its origins, although from the end of the $18^{\text {th }}$ century, and

\footnotetext{
${ }^{4}$ Of the 57 municipalities entirely or partly affected by the park, El Palmar is the only one specifically mentioned in PORN for its cultural and landscape values.

${ }^{5}$ Elver is the flagship species of the El Palmar fishermen and has been one of the most valued catches along with prawn and sea bass. Elver has given rise to several culinary creations associated with the lake. The annual volume of catch in 1950 was around 120,000 kg while today it barely reaches $9,000 \mathrm{~kg}$.
} 
particularly in the $19^{\text {th }}$, rice plantations expanded throughout the Albufera region. ${ }^{6}$ Until the first half of the $20^{\text {th }}$ century fishing and rice-growing were complementary activities of the area. What differentiates the community of El Palmar from other local settlements, however, is that it is the only community that maintains the right of redoli or the right to fish, which originated in a royal privilege granted in the Middle Ages and which has been kept up until today. This involves the distribution of fishing places through an annual draw amongst fishermen. In order to manage this, the participants use their own administrative system: the El Palmar Community of Fishermen. ${ }^{7}$ This body, through the right granted by customary law, is not only responsible for carrying out the draws, but also regulates all local use. In addition, it permeates and regulates all levels of local society and looks after the various resources and services of the town.

It should be pointed out that the fishing world of the Albufera lake has been and is still shaped as a male domain. This is why we refer intentionally to the "fishermen" instead of using a more gender-neutral terminology. It does not mean that women have not participated at all in the fishing world. They were, for example, in charge of the repairing of fishing nets or selling specific types of catches. Nonetheless, women have historically been excluded from the decision-making processes within the Community. ${ }^{8}$ they were not included in the local managerial institution and they were actually banned from fishing ${ }^{9}$ (their dependent status was marked by their roles as sisters, mothers, or wives of fishermen). This social, economic, symbolic and real structural marginalisation has marked the history of women, and of the town, to the extent that women themselves refer to the Community of Fishermen as the institution where the knowledge, history and authority of El Palmar is guarded. It should be stressed that both collective heritage and expert knowledge have been shaped and coded as masculine. Patriarchy, androcentrism and sexism are clearly visible in both of these fields, and although this

\footnotetext{
${ }^{6}$ In almost two centuries $85 \%$ of the lake has been lost to cultivation. The change in the environment to adapt it for agricultural needs - silting - has had important ecological and socioeconomic repercussions.

${ }^{7}$ Sanmartín $(1979,1982)$ has published an extensive ethnographic study on the location.

${ }^{8}$ We will later focus on the role played by the Fishermen Community, since it went beyond the strict limits of the fishing activities ruling with its norms the whole life of the local society.

${ }^{9}$ In recent years, women have fought to win a place within the Community. After a long litigation that ended up in Court, they were admitted in a formal basis. Nowadays they have surrender this right out of social pressures. For further information in this conflict and other gender related issues in El Palmar see Díez (2003) and Vizcaíno (2007, 2008, 2011).
} 
paper focuses on other tensions, pointing out the omnipresence of these structures is essential for a coherent understanding of the social dynamics of the lake world.

The surrounding industrial development of the 1960s and 70s had a tremendous impact on the lake ecosystem and its inhabitants, giving impulse to two interrelated processes. On the one hand, the inhabitants of the villages around the lake left the primary sector for jobs in the industrial sector and the services sector, whilst on the other hand, the thick industrial fabric, the growth in intensive agriculture, and the intense urban development on the coast caused major environmental damage to the lake and its surroundings. This intense human pressure caused water pollution (leading to the disappearance of a part of the aquatic flora and the wildlife in the area, especially birds) and brought about urban development on the coast (with a systematic reduction of grazing land). In the specific case of El Palmar the new socioeconomic and environmental conditions imposed a clear shift in local activity.

In the context of this deterioration, protecting the lake became an urgent matter. In the context of this deterioration, protecting the lake became an urgent matter for locals and municipal experts. There was some consensus that concerted local efforts were needed to prevent further damage. Nevertheless, the management method implemented by the municipal authorities had a vertical hierarchy based on techno-scientific knowledge. According to the inhabitants, the creation of the Albufera Natural Park caused numerous concerns, which in time turned into disappointments. In fact, in the early days the response of the locals included some violent episodes directed towards the facilities (the burning of the jetty and the municipal office) and towards the private property of the municipal experts (the destruction of various private cars) along with the appearance uncompromising ("First people, then ducks" or "Park no, thanks") or downright threatening ("Death to biologists") graffiti.

The conflict and the resistance of the locals to the top-down management of the protected areas occurred because they saw it as an expropriation of a space they considered their own. Similar responses to the pattern have been observed in other processes of patrimonialization (Beltran, Pascual and Vaccaro 2008; Brockington and Igoe 2006; Coca 2008; Cortés 2012; Igoe and Brockington 2007; Selmi and Hirtzel 2007; West, Igoe and Brockington 2006). The arrival of the park was greeted with 
reticence ("Many people did not agree") ${ }^{10}$ and a lot of fears ("Controversy, no: fear!"). The sector which felt the most threatened was the fishing sector, with the fishermen fearing that they would lose the right to fish: "Let's see if they make a national park and take fishing away from us altogether". Many of the fishermen perceived the creation of the park as a threat to their livelihood, which had already been affected by a major decrease in the most highly valued catches (bass and eels, species particularly sensitive to pollution) following the environmental degradation caused by economic development policies. The most heated debates in the Community of Fisherman revolved around the symbolic loss of control over the lake; their real political capacity had been lost long before then.

Later, however, the park would end up being accepted by the fishermen as an urgent necessity given the state of the water, because it offered the only hope of recovery for the lake: "We said: Maybe it will be good for us, maybe it will be good". In this context the inhabitants of El Palmar not only identified the protection of the area as an opportunity to make the authorities take the degradation of the area seriously, but they also believed that the new conservationist guidelines wouldn't affect them. This idea came from their profound conviction that their practices as fishermen had contributed to the conservation of the ecosystem for a very practical reason: survival. The Albufera, as reported on more than one occasion in the meeting minutes ${ }^{11}$ was described by fishermen as "our children's living" and, as such, their "pampered and loved lake" should be protected (Junta de Capítulos, July 7 1968).

Almost 30 years after the creation of the park, its management is criticised as ineffective by the locals who believed that protection would lead to the rapid recovery of the Albufera water and the return to the catches of old times, in both quality and size. The failure of the park to achieve this accounts for their pessimism . One fisherman stated:

\footnotetext{
${ }^{10}$ All the quotations come from various men from El Palmar over the age of 70, who during a lengthy part of their life had worked only in fishing.

${ }^{11}$ For our research we gained access to all the documentation kept in the Community of Fishermen premises. We consulted the files of the Junta de Capítols, the Junta de Redolins and the Junta de Conters, as well as those of the Governing Board and the advisory council. In addition we examined books relating to Artículos, de Préstamos, y de Derechos y Regalías del Patrimonio. We have consequently screened and analyzed these documents. We would like to express our thanks for the generosity of the El Palmar Community of Fishermen for giving us access to the documents and for the trust they placed in our work.
} 
“(the park) is no use. They haven't done anything in the park". Another questioned: "is this the progress we have made in the Natural Park? Bullshit! The Natural Park sucks. Just as it sounds [...] because it is useless. They have done nothing in the Natural Park". Local indignation is all the greater, since the creation of the protected area has meant the introduction of new regulations governing uses and spaces, and local interests have been side-lined: As one fisherman argued: "(What) they have done is prohibit things. On top of doing nothing about the water, they have prohibited things". This complaint is heard frequently in relation to the creation of protected areas. The rejection of the local population emphasises the fact that new protected areas are often the result of top-down decision making processes (Beltran, Pascual and Vaccaro 2008; Beltran and Vaccaro 2010; Pascual and Florido 2005; Vaccaro and Beltran 2010, amongst others). The most frequent complaints expressed by the inhabitants of El Palmar were related to regulations of activities and to the rules limiting the use of natural resources, which in some cases meant prohibiting local practices which the inhabitants perceived as traditional.

In this way, the inhabitants of El Palmar believe that the creation of the park has led to the restriction of their movements, and it is seen as a clear expropriation of the territory. Places where locals used to move around freely are now restricted areas: As one local fisherman explained: "They say Devesa is now a Natural Park, and it will have to be natural, but the thing is that you are used to taking walks around there and now you try and you are not allowed"; "Before you could go in there and now you can't get in because they have put stakes or whatever"; "Well maybe you put a stake here, because there are nesting birds, so here you can't pass, and you have to turn around and all that... Disadvantages, and more disadvantages. Disadvantages for some and salaries for others." The local people further point to the rules that limit traditional activities. Fishing is not the only activity affected by the creation of the protected area, the hunting ban is also often pointed out as a reason for the locals' rejection of the park: "We have always been able to go shooting in the Albufera. Since the park was created, the hunters haven't been able to shoot any more"; "Before, they had hunting days every year [...] and now it's not allowed. They don't let you hunt: it's all natural!" "Then they prohibited hunting. And in the end well... they told us not to go shooting anymore".

\section{Not Biologists, but we, the People of Albufera}


The replies given by the inhabitants of El Palmar provide evidence of the opposing views of the experts and the local population over knowledge and interests. With the creation of the park the locals lost the capacity to regulate the lake, which until then had been in their hands due to their historic privileges (Sanmartín, 1982). The rules of the El Palmar Community of Fishermen ${ }^{12}$, based on their knowledge of the environment and agreed upon by the members, were marginalised. The documentation of the body contains numerous references to agreements (timetables, techniques and catches) aimed at regulating the use and guaranteeing the sustainability of the lake's resources. For example, we find the prohibition of certain techniques for being considered damaging. "They have agreed on the prohibition of gear that harm the interests of lives, that is, of fishing lives [...] 'Compañia' ${ }^{13}$, 'gánguil de arrastre' ${ }^{14}$, 'mornell' ${ }^{15}$, and fishing shrimp for selling, are prohibited" (Junta de Capítulos, June 15, 1915). Similarly, closed seasons were established for the regeneration of the species: "The closed season will take place from the first of June to the first of August and no one is allowed to fish, neither from within the community nor any outsider" (Junta de Capítulos, May 17, 1922). The Community also made political efforts to ensure the conservation of the species of the lake: "The Jury explains the trip to Madrid [...] They said that fishermen from outside of the Community were at the lake mouth and collected large amounts of small eels in winter time from December to March, and this is very harmful for the reproduction of the lake and the Albufera, and will lead to us not being able to provide for our children" (Junta de Capítulos, January 17, 1936). This mismatch between the different types of knowledge, which led to the imposition of the policies of knowledge, is also a normalized mechanism in the modern processes of territorial intervention (Beltran and Vaccaro 2014; Cortés, Quintero and Valcuende 2011; Santamarina 2009; Valcuende, Quintero and Cortés 2011).

The restrictions imposed, the lack of dialogue and the exclusion of the Community of Fishermen (and even of the El Palmar municipality) from the management and decision-making in the protected area generated outright opposition to the park. The

\footnotetext{
${ }^{12}$ It has to be emphasized that this body has functioned historically as the institution which regulates not only fishing but the entire social organization of El Palmar (Sanmartín 1982). Together with the Tribunal de las Aguas, it is the oldest institution in Valencia governed by Common Law.

${ }^{13}$ A traditional fishing technique.

${ }^{14}$ A traditional fishing technique, similar to hopper trawl fishing.

${ }^{15}$ A type of funnel for eel fishing.
} 
public administration showed scant interest in explaining to those affected what the creation of the park would mean, nor did they seek ways of encouraging participation, and thus contributed to resentment and rumours about the creation of the Natural Park. The perception of an external threat and the lack of communication can explain the seriousness of the incidents at the beginning of the process. The combination of policies justified by techno-ecological (scientific) criteria and the repudiation of the locals undermined any chance of building bridges between the different stakeholders.

Given this context, the words used by a 78 year old fisherman to refer to Albufera after the creation of the Natural Park reveal anger and indignation:

"We have looked after it better than anybody... Our entire lives. The people who have looked after Albufera are the fishermen. No one has loved Albufera like the fishermen, never. No one has looked after it better than we have. . Not biologists, not anyone. No one. What the biologists know about Albufera they have learned from us". ${ }^{16}$

His words are telling in relation to two fundamental points. Firstly, the local people believe have preserved the environment better than anyone. When speaking of fishermen he refers the Community of Fishermen as a subject and expresses the conviction that they have been the real "conservers" of the lake, the marshland and grazing areas, since they have always protected the ecosystem in order to guarantee the sustainability of the resources ${ }^{17}$. Secondly, the locals believe knowledge of the "biologists" has undoubtedly stemmed from the locals themselves. In this respect the people of El Palmar consider that they alone have the "only and true knowledge" of their environment, acquired and socially transmitted over the ages. From this perspective, the scientific and technological criteria cannot compete with deep-seated local practices based on experience and accumulated wisdom. If they do so, they must recognise that the origin of that knowledge is none other than local knowledge "they learnt from us".

\footnotetext{
${ }^{16}$ Literal translation from Valencian.

${ }^{17}$ The potentiality of local practices to sustain natural resources is a discourse frequently expressed uncritically by anthropologists. However, there is a need to take a more nuanced approach adapted to each case when speaking of the break which modernity has imposed on traditional systems of environmental management systems with its intensive exploitation and its impact on ecosystems.
} 
This allows for a better understanding of the ambiguous position taken by the residents of El Palmar towards the heritagisation of nature in their territory. On the one hand they want protection for the area in order for the seriously damaged ecosystem to recover. They have good reasons to wish for this: the regeneration of the lake (the memory of the crystal clear waters of the lake in the old days linked to the abundance of fish is still strong in the collective imagination); the satisfaction and pride in the recognition of the place as a collective heritage; and the development of a tourist sector associated with this heritagisation. In the last 50 years the inhabitants of El Palmar have gone from living from the Albufera to depending increasingly on a fully consolidated tertiary economy. ${ }^{18}$ Natural heritagisation, with the creation of the park, and cultural heritagisation - including, for instance, the exploitation of local gastronomy and the reinvention of regional folklore (the Albufera has been constructed as an icon of Valencian identity) - today provide the foundation of the local economy.

On the other hand, the inhabitants of El Palmar are against an imposed conservation regime because it denies them their history (their consolidated rights), it prevents them from administering their own resources (the Community of Fishermen), and it confiscates their land, both symbolically and in reality (prohibition on use). The creation of the Natural Park has involved new regulations for the uses and spaces of the territory, stemming from preconceived notions of conservation that are far from the locals' vision for the park. The type of conservation regime implemented is based on policies rooted in technical and scientific knowledge which dictates how, why, for what and for whom the area should be conserved, using 'truth' criteria. This marginalises local interests and gives priority to scientific rationality as the legitimate model for implementing the new land use plan. The denial of the political and epistemic use of local knowledge not only wipes clean the genealogies of local landscapes, but it also denies a voice to those who have been the most important actors in the landscape. This way, a knowledge situated in a historic, scientific and rational subject is replaced by the knowledge of a transcendent and untraceable subject. When the locals call all experts

\footnotetext{
${ }^{18}$ According to data from the Valencia City Council there are a total of 46 establishments related to commerce or hotels and restaurants for a total of 788 inhabitants. Although at the end of the 20th century the number of restaurants saw meteoric growth, almost one a year, at the beginning of this century the number has leveled off due to the saturation of the local gastronomic market.
} 
biologists they are demonstrating that scientific practice is politics and that politics uses scientific practice to hide truth regimes and governance processes.

\section{Conclusions: Knowledge, Heritage, Strategies, and Logic}

The case of El Palmar demonstrates only one kind of natural heritagisation and corresponds to the so-called Authorized Heritage Discourse referred to by Smith (2006). It also works as a good illustration of the resistance to the imposition of a hegemonic pattern. There are many ways of managing normative knowledge and of deploying strategies to create and construct heritage. Different types of knowledge play different roles, not only in configuring the various types of heritage but also in the use given to them by the various heritagising agents. It is therefore important to note that normalised knowledge, whilst capable of shifting or resituating marginal knowledge to favour the hegemonic discourse, can also be used by local actors for the opposite purpose, in constructing a counter-hegemonic discourse.

With regard to the use of different types of knowledge by different heritagising agents, we can conclude that science can be used equally as a potent legitimising argument by the challenging discourse and it is to these challenges we now turn. Heritage construction has gained increasing prominence within the context of civil protest movements. Since the 1990s, there have been a number of movements in Spain, which, have used the expression "Save...", and which have been defined as associations in defence of heritage. ${ }^{19}$ Although the ends and means used have differed, they have all sought legitimacy through academic discourse. This is the case of the "Salvem el Cabanyal" movement, which emerged in opposition to a large building project in a neighbourhood of Valencia, a movement which gained considerable legitimacy from the credible support of two public universities in the city. ${ }^{20}$ The academic support, in the form of expert reports, manifestos and demonstrations, has endowed the group with persuasive tools, both to influence public opinion and to convincingly negotiate with political institutions. The promotion of collective heritage by various disciplines has made a decisive contribution to holding back the town's development plans.

\footnotetext{
${ }^{19}$ Cucó (2009) and Gómez Ferri (2004) provide an analysis of these movements.

${ }^{20}$ In their wide-ranging website (http://www.cabanyal.com/) there is an important database of documents and numerous expert reports (architectural, legal, sociological, cultural, etc.)
} 
In El Cabanyal there is a group that openly defines itself as a counter-hegemonic alternative to existing powers and that does not seek acquiescence but rather confrontation through appeals to the authenticity of local cultural heritage. It is the case of a heritagisation process seeking conflict and turning to heritagisation as part of the strategy. In this case, the different social actors always count on a measure of expert knowledge to endorse their discourse, in granting value to and protecting heritage. Scientific language provides a tool as seductive as it is effective in providing the heritage artifact with authenticity.

The heritage factory, in Heinich's (2009) words, needs 'authentic' markers of identity in order to lubricate a machine which produces the past and gives meaning to the present (MacDonald 2013). Not only that: truth, dogmatic truth, makes it possible to govern the past in order to control the present. From this stems the fight over meanings. In this way, the patrimonial apparatus works as an arena where distinctions are bestowed within an imagined consensual objectivity and under the vigilant scrutiny of disciplinary regimes. Heritage is in this sense a complex cultural construction intersects with the past, memory, identity and territory. It is within the heritage context that cultural practices, codified under the influence of judgements bound together around authenticity, are condensed, reified and reinvented. Therefore, authenticity plays a central role within heritage and bestows it with significance. Authenticity is a subjective concept, which when applied to heritage provides it with a distinctive value that merits protection or safeguarding. The only way of making the determination of authenticity objective or neutral, is to turn to science -the instrument responsible for producing truths. Calling upon the objectivity of science ignores the fact that science is a social construction in itself; that objectivity is a subjective judgement; and that neutralisation is a kind of submission.

The hegemonic discourse of heritage uses disciplinary resources to establish convenient distinctions and to dominate other types of knowledge that are then subjugated. In order to stand up to this, the counter-hegemonic discourse uses the same tactics deployed by its opponent to equip itself with its own rationale and resignify practices. When the inhabitants of El Palmar refer to the park experts as biologists they are using irony as an 
intelligent way of defining reality, a way which has no official recognition but that is particularly eloquent.

\section{References}

Ariño, A. 2002. La Expansión del Patrimonio Cultural. Revista de Occidente 250: 129-150.

Bauman, Z. 2001. Community: Seeking Safety in an Insecure World. Cambridge: Polity Press. Bauman, Z. 2004. Identity. Cambridge: Polity Press.

Beltran, O., J. Pascual, and I. Vaccaro, eds. 2008. Patrimonialización de la Naturaleza. El Marco Social de las Políticas Ambientales. Donostia: Ankulegi.

Beltran, O. and I. Vaccaro. 2010. From Scenic Beauty to Biodiversity. The Patrimonialization of Nature in the Pallars Sobirà (Catalan Pyrenees). In Constructing Cultural and Natural Heritage. Parks, museums and rural heritage, edited by X. Roigé and J. Frigolé, 91-104. Girona: ICRPC.

Beltran, O., and I. Vaccaro. 2014. Parcs als Comunals. La Patrimonialització de la Muntanya al Pallars Sobirà. Barcelona: Generalitat de Catalunya.

Bendix, R. F. 2009. Heritage between Economy and Politics: An Assessment from the Perspective of Cultural Anthropology. In Intangible Heritage, edited by L. Smith and N. Akagawa, 253-269. London: Routledge.

Bendix, R. F., A. Eggert and A. Peselmann, eds. 2012. Heritage Regimes and the State. Göttingen: Universitätsverlag Göttingen.

Boltanski, L. and E. Chiapello. 2002. El Nuevo Espíritu del Capitalismo. Madrid: Akal.

Bortolotto, Ch. 2011. Le Trouble du Patrimoine Culturel Immatériel. In Le Patrimoine Culturel Immatériel: Enjeux d'une Nouvelle Catégorie, edited by Ch. Bortolotto, 21-43. Paris: Maison des Sciences de l'Homme.

Bourdieu, P. 1980. Le Sens Pratique. Paris: Éditions de Minuit.

Bourdieu, P. 1984. Distinction: A social Critique of the Judgement of Taste. Cambridge: Harvard University Press.

Bourdieu, P. 1994. Raisons Pratiques: Sur la Théorie de l'Action. Paris: Seuil.

Briggs, Ch. L. 1996. The Politics of Discursive Authority in Research on the 'Invention of Tradition'. Cultural Anthropology 11 (4): 435-469.

Brockington, D., and J. Igoe. 2006. Eviction for Conservation: A Global Overview. Conservation and Society 4 (3): 424-470. 
Caruana, C. 1954. Estudio Histórico-jurídico de la Albufera de Valencia, su Régimen y Aprovechamientos desde la Reconquista hasta Nuestros Días. Valencia: Sucesor de Vives Mora.

Chaves, M., M. Montenegro, and M. Zambrano, eds. 2014. El Valor del Patrimonio: Mercado, Políticas Culturales y Agenciamientos Sociales. Bogotá: Instituto Colombiano de Antropología e Historia.

Choay, F. 1996. L'Allégorie du Patrimoine. Paris: Seuil.

Coca, A. 2008. Los Camperos. Territorios, Usos Sociales y Percepciones en un Espacio Natural Andaluz. Sevilla: Fundación Blas Infante.

Comaroff, J. L., and J. Comaroff. 1991. Of Revelation and Revolution. Chicago: University of Chicago Press.

Cortés, J. A. 2012. Naturalezas en Conflicto: Conservación Ambiental y Enfrentamiento Social en el Parque Natural Cabo de Gata-Níjar. Valencia: Germania-AVA.

Cortés, J. A., V. Quintero, and J. M. Valcuende. 2011. La Naturaleza como Patrimonio: Una Categoría en Disputa en el Parque Natural Cabo de Gata-Níjar. In Consumir Naturaleza: Productos Turísticos y Espacios Protegidos en Andalucía, edited by J. Escalera, 21-48. Sevilla: Aconcagua.

Cucó, J. 2009. Urbanización y Revuelta. Aproximación al Caso de la Ciudad de Valencia. Zainak. Cuadernos de Antropología-Etnografía 32: 549-559.

Davallon, J. 2010. The Game of Heritagization. In Constructing Cultural and Natural Heritage. Parks, Museums and Rural Heritage, edited by X. Roigé and J. Frigolé, 2738. Girona: ICRPC.

Del Mármol, C. 2012. Pasados Locales, Políticas Globales. Procesos de Patrimonialización en un Valle del Pirineo Catalán. Valencia: Germania-AVA.

Del Mármol, C., J. Frigolé, and S. Narotzky, eds. 2010. Los Lindes del Patrimonio: Consumo y Valores del Pasado. Barcelona: Icaria

Díez, C. 2003. Tradiciones Culturales y Legitimación del Poder Masculino. Gazeta de Antropología 19(15):1-15.

Escobar, A., and E. Restrepo. 2010. Territorios de Diferencia: Lugar, Movimientos, Vida, Redes. Popayán (Colombia): Envión.

Foucault, M. 1970. The Order of Things: An Archaeology of the Human Sciences. London: Tavistock.

Foucault, M. 1977. Discipline and Punishment: The birth of the prison. London: Tavistock. 
Foucault, M. 1980. Power/Knowledge: Selected Interviews and Other Writings, 1972-1977. New York: Pantheon.

Foucault, M. 1991. Saber y Verdad. Madrid: La Piqueta.

Franquesa, J. 2013. Urbanismo Neoliberal, Negocio Inmobiliario y Vida Vecinal. El Caso de Palma. Barcelona: Icaria.

Frigolé, J. 2014. Retóricas de la Autenticidad en el Capitalismo Avanzado. Endoxa 33: 37-60.

García Canclini, N. 1993. Los Usos Sociales del Patrimonio Cultural. In El patrimonio Cultural de México, edited by E. Florescano, 41-62. México: Fondo de Cultura Económica.

Goldman, M. 2001. The Birth of a Discipline. Producing Authoritative Green Knowledge World-Bank Style. Ethnography 2 (2): 191-217.

Gómez Ferri, J. 2004. Del Patrimonio a la Identidad. La Sociedad Civil como Activadora Patrimonial en la Ciudad de Valencia. Gazeta de Antropología 20 (9).

González-Varas, I. 2003. Conservación de Bienes Culturales: Teoría, Principios y Normas. Madrid: Cátedra.

Hafstein, V. 2011. Célébrer les Différences, Renforcer la Conformité. In Le Patrimoine Culturel Immatériel: Enjeux d'une Nouvelle Catégorie, edited by Ch. Bortolotto, 75-97. Paris, Maison des Sciences de l'Homme.

Hall, S. 2003. Who Needs 'Identity'?. In Questions of Cultural Identity, edited by S. Hall and P. Du Gay, 1-17. London: Sage.

Haraway, D. 1991. Simians, Cyborgs, and Women: The Reinvention of Nature. New York: Routledge.

Harvey, D. C. 2001. Heritage Pasts and Heritage Presents: Temporality, Meaning and the Scope of Heritage Studies. International Journal of Heritage Studies 7(4): 319-338.

Harvey, D. C. 2008. The History of Heritage. In The Ashgate Research Companion to Heritage and Identity, edited by B. Graham and P. Howard, 19-36. Aldershot: Ashgate.

Heinich, N. 2009. La Fabrique du Patrimoine. De la Cathédrale à la Petite Cuillère. Paris: Maison des Sciences de l'Homme.

Hernández, G.; B. Santamarina, A. Moncusí, and M. Albert. 2005. La Memoria Construida. Patrimonio Cultural y Modernidad. Valencia: Tirant Lo Blanch.

Herzfeld, M. 2004. The Body Impolitic: Artisans and Artifice in the Global Hierarchy of Value. Chicago: University of Chicago Press.

Herzfeld, M. 2006. Spatial Cleansing. Monumental Vacuity and the Idea of the West. Journal of Material Culture 11(1-2): 127-149. 
Herzfeld, M. 2010. Engagement, Gentrification, and the Neoliberal Hijacking of History. Current Anthropology 51(2): 259-268.

Igoe, J., and D. Brockington. 2007. Neoliberal Conservation: A Brief Introduction. Conservation and Society 5(4): 432-449.

Kirshenblatt-Gimblett, B. 1998. Destination Culture. Tourism, Museums, and Heritage. Berkeley: University of California Press.

Kirshenblatt-Gimblett, B. 2004. Intangible Heritage as Metacultural Production. Museum international 56 (1-2): 52-65.

Lander, E., ed. 2000. La Colonialidad del Saber: Eurocentrismo y Ciencias Sociales. Buenos Aires: CLACSO.

MacDonald, S. 2013. Memorylands. Heritage and Identity in Europe Today. London: Routledge.

Maffesoli, M. 1993. El Conocimiento Ordinario. Compendio de Sociología. México: Fondo de Cultura Económica.

Maffesoli, M. 1997. Elogio de la Razón Sensible. Una Visión Intuitiva del Mundo Contemporáneo. Barcelona: Paidós.

Maguet, F. 2011. L'Image des Communautés dans l'Espace Public. In Le Patrimoine Culturel Immatériel: Enjeux d'une Nouvelle Catégorie, edited by Ch. Bortolotto, 47-73. Paris, Maison des Sciences de l'Homme.

Mignolo, W. D. 2012. Local Histories/Global Designs: Coloniality, Subaltern Knowledges, and Border Thinking. Princeton: Princeton University Press.

Montenegro, M. 2010. La Patrimonialización como Protección contra la Mercantilización: Paradojas de las Sanciones Culturales de lo Igual y lo Diferente. Revista Colombiana de Antropología 46: 115-131.

Noyes, D. 2011. La Fête ou le Fétiche, le Geste ou la Gestion. Du Patrimoine culturel Immatériel comme Effet Pervers de la Démocratisation. In Le Patrimoine Culturel Immatériel: Enjeux d'une Nouvelle Catégorie, edited by Ch. Bortolotto, 125-48. Paris, Maison des Sciences de l'Homme.

Palumbo, B. 2010. Sistemi Tassonomici dell'Immaginario Globale. Prime Ipotesi di Ricerca a Partire dal Caso Unesco. Meridiana 68: 37-72.

Pascual, J., and D. Florido, eds. 2005. ¿Protegiendo los Recursos? Áreas Protegidas, Poblaciones Locales y Sostenibilidad. Sevilla: Fundación Monte.

Poulot, D. 2006. Une Histoire du Patrimoine en Occident, XVIII-XIX siècle. Du Monuments aux Valeurs. Paris: Presses Universitaires de France. 
Roigé, X. and J. Frigolé, eds. 2010. Constructing Cultural and Natural Heritage. Parks, Museums and Rural Heritage. Girona: ICRPC.

Sánchez-Carretero, C. 2012. Heritage Regimes and the Camino de Santiago: Gaps and Logics.

In Heritage Regimes and the State, edited by R. F. Bendix, A. Eggert, and A. Peselmann, 141-155. Göttingen: Universitätsverlag Göttingen.

Ribeiro, G. L., and A. Escobar, eds. 2008. Antropologías del Mundo: Transformaciones Disciplinarias dentro de Sistemas de Poder. Popayán (Colombia): Wenner-Gren Foundation for Anthropological Research, Ciesas and Envión.

Rosselló, V. M. 1995. L'Albufera de València. Barcelona: Publicacions de l'Abadia de Montserrat.

Sanmartín, R. 1979. Los Pescadores de El Palmar. In Vaqueiros y Pescadores. Dos Modos de Vida, edited by M. Cátedra and R. Sanmartín, 95-173. Madrid: Akal.

Sanmartín, R. 1982. La Albufera y sus Hombres. Madrid: Akal.

Santamarina, B. 2009. De Parques y Naturalezas. Enunciados, Cimientos y Dispositivos. Revista de Dialectología y Tradiciones Populares 64(1): 297-324.

Santamarina, B., ed. 2012. Geopolíticas Patrimoniales: de Culturas, Naturalezas e Inmaterialidades. Una Mirada Etnográfica. Valencia: Germania-AVA.

Santamarina, B. 2013. Los Mapas Geopolíticos de la Unesco: entre la Distinción y la Diferencia están las Asimetrías. El Éxito (Exótico) del Patrimonio Inmaterial. Revista de Antropología Social 22: 263-286.

Santamarina, B. and A. Moncusí. 2015. El Mercado de la Autenticidad: las Nuevas Ficciones Patrimoniales. Revista de Occidente 440-441: 93-112.

Santamarina, B. and A. Vizcaino. 2011. El Marjal de la Albufera: De Paisajes, Pescadores y Arroceros. In Museu Valencià d'Etnologia, 193-201. Valencia: Diputación de Valencia.

Selmi, A. and V. Hirtzel. 2007. Parquer la Nature. Cahiers d'Antropologie Sociale 3: 9-12.

Smith, L. 2004. Archaeological Theory and the Politics of Cultural Heritage. London: Routledge.

Smith, L. 2006. Uses of Heritage. New York: Routledge.

Soria, J.M. and E. Vicente. 2002. Estudio de los Aportes Hídricos al Parque Natural de la Albufera de Valencia. Limnetica 21: 105-15.

Vaccaro, I., and O. Beltran, eds. 2010. Social and Ecological History of the Pyrenees. State, Market, and Landscape. Walnut Creek: Left Coast.

Valcuende, J. M., V. Quintero and J. A. Cortés. 2011. Naturalezas Discursivas en Espacios Protegidos. AIBR Revista de Antropología Iberoamericana 6(1): 27-56. 
Vizcaíno, A. 2007. La Albufera y sus Mujeres. Proceedings Publication IX Congreso Nacional de Sociología. Barcelona.

Vizcaíno, A. 2008. La Lucha de las Mujeres de El Palmar (Albufera de Valencia) por el Igual Acceso a los Recursos. Proceedings Publication I Congreso Internacional sobre Género, Trabajo y Economía Informal. Elche.

Vizcaíno, A. 2011. Las Mujeres de El Palmar. Un Análisis de Prensa. Proceedings Publication III Jornadas Asociación Valenciana de Antropología. València.

West, P., J. Igoe, and D. Brockington. 2006. Parks and Peoples: The Social Impact of Protected Areas. Annual Review of Anthropology 35: 251-277. 